УДК 664.047

(C) 2016

Дмитриков В. П., доктор технічних наук, професор,

Назаренко О. О., кандидат технічних наук,

Запорожець М. І., кандидат технічних наук, доцент

Полтавська державна аграрна академія

\title{
МОДИФІКОВАНА ТЕХНОЛОГІЧНА ЛІНІЯ ВИРОБНИЦТВА ЕКСПАНДОВАНИХ КОМБІКОРМІВ
}

\section{Рецензент - доктор технічних наук О. М. Костенко}

Визначено проблеми, щзо склалися у сфері виробниитва зернових комбікормів. Розібрано будову $i$ компоновку гнучких технологічних ліній з переробки аграрної сировини. Проаналізовано фактори впливу на екструзійні процеси переробки продукиії рослинництва. Запропоновано модифіковану технологічну лінію виробництва експандованих комбікормів різного призначення.

Ключові слова: аграрна сировина, експандер, комбікорми, модифікація технологічної лінії, прочес переробки.

Постановка проблеми. В сучасних соціальноекономічних умовах особливого значення набуває підвищення ефективності виробництва кормів, так як на приготування кормів витрачається 20-60\% усіх затрат праці по виробництву продукції.

Механізація приготування кормів значно розширює їх асортимент для різних видів тварин. Виробництво і виготовлення брикетів, гранул, різних видів консервованих кормів, створення кормосумішів, підбір компонентів, покращання доступності живильних речовин, вимагає створення високотехнологічного обладнання, здатного замінити комплекс машин і отримати високий економічний ефект.

До найбільш високоефективних способів переробки аграрної сировини відносять термопластичну екструзійну обробку, котра суміщає термо-, гідро- і механічну дію на компоненти, що дає змогу отримувати комбікорми 3 новими властивостями текстур 3 переважним для організму тварини балансом живильних речовин і вищою засвоюваністю. Прес-експандери забезпечують механічну дію на сировину, ефективно руйнуючи структуру матеріалу, тим самим підвищуючи поживність і якість кормів. Такий обробіток пов'язаний з високими температурами до $130{ }^{\circ} \mathrm{C}$ і тиском до 3,0 МПа.

Аналіз останніх досліджень і публікацій, у яких започатковано розв'язання проблеми. Результати аналізу літературних джерел з метою визначення пріоритетних напрямів розвитку технологій експандування комбікормів вказують на перспективність нових підходів до переробки рослинної сировини 3 метою використання в кормових виробництвах.

Одним із найбільш поширених методів обробки аграрної сировини є ії екструдування. Сировина різко збільшується в об ємі, в результаті механічних навантажень і теплоти проходять суттєві фізико-хімічні зміни компонентів готового продукту.

Підвищити ефективність процесу екструдування, знизити питомі витрати електроенергії можна, використовуючи попереднє пропарювання продукту при тиску 0,1-0,3 МПа до вологості $17-18 \%$ [1].

Попереднє експандування сприяє підвищенню ефективності технологічного процесу гранулювання комбікорму, оскільки комбікорм надходить на гранулювання зволоженим до 16-18 \% і розігрітим до температури $90-115^{\circ} \mathrm{C}$, а також ущільненим. У результаті зростає продуктивність пресів-грануляторів, зменшуються питомі витрати електроенергії на отримання однієї тонни гранул. Змінюючи кільцевий зазор у матриці експандера, можна регулювати міцність гранул комбікорму [4].

Використання експандерів дає змогу отримувати готовий продукт у вигляді комбікормової крупки без гранулювання розсипного комбікорму. В цьому випадку суттєво зростає продуктивність технологічного процесу отримання комбікормової крупки і зменшуються питомі витрати.

Аналіз тенденцій розвитку виробництва кормових продуктів показує, що в найближчому майбутньому вироби такого вигляду займуть важливе місце під час створення комбінованих продуктів [3].

Основні переваги вдосконаленої технології виробництва експандату полягають у можливості організації гнучких технологічних схем, високій продуктивності і малих габаритах експандерів, 


\section{TEХНІЧНІ НАУКИ}

безперервності процесу i низької собівартості продукції.

Метою роботи $\epsilon$ вдосконалення технології виробництва комбікормів, котрі отримують способом термопластичної екструзії 3 рослинної сировини.

Завдання досліджень: аналіз факторів впливу на технологічний процес переробки рослинної сировини 3 подальшою модифікацією технологічної лінії виробництва експандованих структурованих комбікормів (ЕСК).

Матеріали і методика досліджень. Загальна методологічна основа досліджень використовувала системний підхід, що забезпечує розгляд процесу приготування експандованих комбікормів з урахуванням взаємозв'язків технологічних i конструктивних параметрів технічних засобів технологічної лінії. Для вирішення поставлених завдань використовували методи математичного моделювання і абстрактно-логічний метод.

Результати досліджень. Технологія експандування є одним із кращих способів кондиціювання комбікормів та окремих компонентів [2]. Експандування засновано на гідротермічній обробці рослинної сировини під тиском. Обробка комбікорму в експандері здійснюється за більш високої вологості, ніж в екструдері.

Провідні західні фірми рекомендують проводити обробку сировини в разі вологості до $26 \%$. Продукт розігрівається за рахунок введення пари і тертя. В експандері відсутні «гріючі» шайби.

За тих самих температурних режимів (115$\left.145^{\circ} \mathrm{C}\right)$ обробка в експандері у випадку підвищеної вологості протікає в менш жорстких умовах. В екструдері через знижену вологість на окремих ділянках «місцеві» опори руху продукту можуть зрости до значних величин, викликаючи «місцеве» підвищення температури, хоча загальний температурний режим не змінюється. Як в екструдерах, так і експандерах можна за рахунок зміни режимів обробки одержувати готовий продукт різної щільності [2].

Експандування має низку переваг: введення великої кількості рідких компонентів - олії, жиру, меляси тощо; усунення шкідливих для харчування речовин; поліпшення якості і засвоюваності комбікормів; більш високу продуктивність пресів для гранулювання; кращу якість гранул; використання більш дешевої для гранулювання сировини; можливість виробництва негранульованого експандату.

Це завдання вирішується iз застосуванням процесу експандування і експандерів, що випускаються фірмами AMANDUS KAHL, ALMEX, ANDRITZ тощо.
Нормальна робоча температура під час обробки комбікормів для птиці і свиней перебуває в діапазоні $105-110^{\circ} \mathrm{C}$.

Можна досягти тиску до 4 МПа і температури до $130{ }^{\circ} \mathrm{C}$, але всього лише на дуже короткий період, тому що загальний час проходження продукту через експандер становить кілька секунд.

На виході з експандера продукт миттєво втрачає навантаження, а додана рідина в значній мірі випаровується. За рахунок випаровування рідини температура падає до $90^{\circ} \mathrm{C}$. Залежно від рецептури, температури продукту і тиску готовий продукт може мати структуру тіста, товстих пластівців або шматків [6].

Гранульований експандат поєднує у собі одночасно переваги гранульованих i розсипних комбікормів. Кожна часточка містить усі компоненти; розподіл часток украй рівномірний.

Можна регулювати розмір часток зазором у вальцьовому подрібнювачі і одержувати розсипний комбікорм без таких недоліків, як погана плинність і розшарування суміші.

Експандування дає змогу досягти однакового або більш високого ступеню модифікації крохмалю в порівнянні $з$ попереднім запарюванням, що позитивно впливає на процес перетравлювання комбікорму.

На рисунку наведено модифіковану технологічну схему експандування розсипних комбікормів фірми AMANDUS KAHL [2]. Особливістю даної схеми $є$ введення в структуру блоку енергозберігання з програмним управлінням, що покращує енергетичні й економічні показники роботи технологічної лінії.

У складі технологічної схеми виробництва комбікормів є три головні ділянки: склад зерна i відділення для зберігання та підготовки додаткової сировини, головне виробництво, сховище продукції.

Експандування кормів без гранулювання дає можливість отримати ЕСК. Експандований структурований корм - корм, який проходить гідротермічну обробку за допомогою експандера i призначений для безпосереднього згодовування у вигляді шматків без гранулювання. ЕСК може бути моноелементний корм, концентрат із високим умістом обмінної енергії, білковий концентрат або готовий до споживання комбікорм [5].

ЕСК можна згодовувати поросятам і свиням у сухому і напіврідкому вигляді; молочним тваринам, переважно в разі підмішування до загального корму разом із грубими кормами; курамнесучкам під час вирощування і отримання товарних яєць; поголів'ю птиці, особливо в перші тижні життя. 


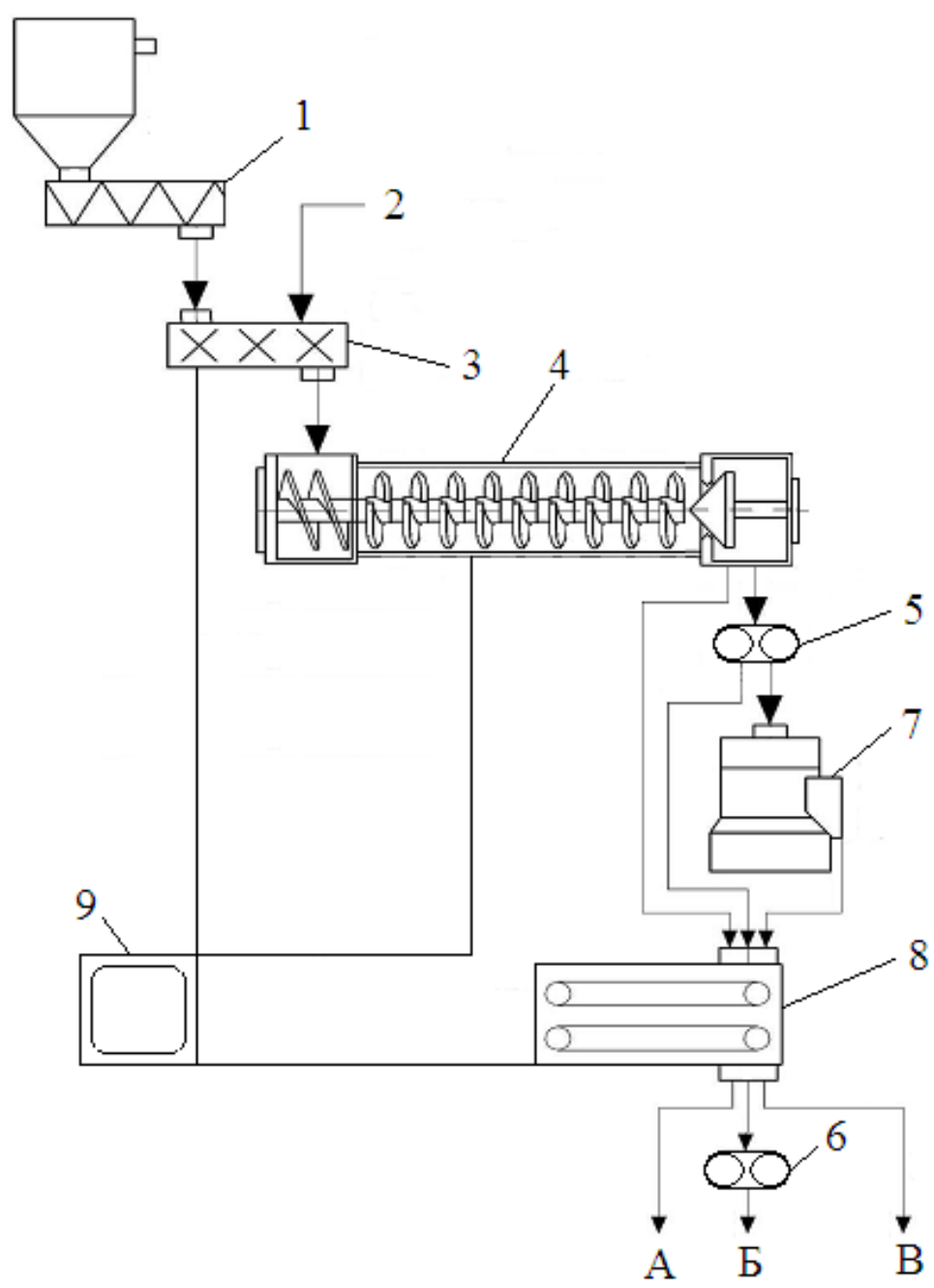

1 - дозувальний шнек, 2 - кормові добавки, 3 - змішувач безперервної дії, 4 - експандер із кільцевим зазором, 5, 6 - подрібнювачі, 7 - прес-гранулятор, 8 - охолоджувач, 9 - блок енергозбереження 3 програмним забезпеченням; А - грубий експандат; Б - подрібнений експандат; В - гранульований експандат

\section{Рис. Модифікована технологічна схема експандування комбікормів фірми AMANDUS KAHL}

ЕСК оптимальний для свиней, оскільки шматки на відміну від грануляту не настільки тверді, тому не травмують стравохід і шлунок; крупнозернисті шматки не утворюють пилу і тим самим не викликають склеювання органів жування і дихання; на відміну від борошна та гранул шматки експандату легко розчиняються у воді, зберігають стабільність та стійкість під час переміщення, що важливо під час згодовування свиням у напіврідкому вигляді; шматки мають більшу поверхню частинок і пористу структуру, що забезпечує більш легке проникнення до них всередину шлункового соку і ферментів.

ЕСК завдяки розчинності у воді особливо придатний для згодовування у рідкому стані, крім води він добре диспергується в інших ріди- нах, таких як молочна сироватка або «супи» 3 харчових відходів. Для розведення експандату у воді необхідно менше часу, ніж для розведення грануляту чи борошна.

Висновок. Проаналізовано процеси експандування аграрної сировини різної за складом та фізико-механічними властивостями для виробництва комбікормів. Обгрунтовано модифіковану технологічну лінію виробництва ЕСК, котрі виготовляються із аграрної сировини з використанням сумішів зернових, бобових та інших харчових компонентів. Запропонована авторами модифікація виробництва експандату передбачає виробництво нового типу комбікормової продукції на основі рослинної і тваринної сировини. 


\section{БІБЛІОГРАФІЯ}

1. Бойко Л. Н. Прогресивные технологии для производства комбикормов [текст] / Л. Н. Бойко // Комбикорма. - 2005. - №4. - С. 23-24.

2. Экспандер с кольцевым зазором фирмы «KAHL» [Электронный ресурс]. - Режим доступа : http://www.akahl.de/akahl/ru/ru_produkte/ru_ tiernahrung/ru_ringspalt-expander/.

3. Розроблення екструдатів підвищеної біологічної цінності [текст] / [Ковбаса В. М., Махинько Л. В., Герасименко О. В., Шаран А. В., Піддубний В. А.] // Зернові продукти і комбікорми. 2005. - №1. - C. 29-31.
4. Крони Л. И., Генхтун Г. С. Производство комбикормов и кормових смесей [текст] / Л. И. Крони, Г. С. Генхтун. - К. : Урожай, 1993. $187 \mathrm{c}$.

5. Шестернина С. А. Применение экструзионной технологии в комбикормовой промышленности [текст] / С. А. Шестернина // Обзорн. информ. - М. : ЦНИИТЭИ хлебопродуктов, 1994. $29 \mathrm{c}$.

6. Повышение эффективности производства комбикормов [текст] / [Шевцов А. А., Остриков А. Н., Лыткина Л. И., Сухарев А. И.]. - М. : ДеЛи Принт, 2005. $-243 \mathrm{c}$. 